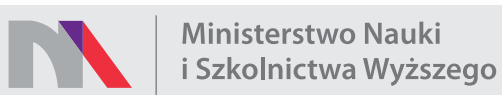

Digitalizacja archiwalnych numerów czasopisma naukowego Analecta Cracoviensia 1-24 (1969-1992) i ich publikacja w otwartym dostępie - zadanie finansowane w ramach umowy 672/P-DUN/2017 ze środków Ministra Nauki i Szkolnictwa Wyższego przeznaczonych na działalność upowszechniającą naukę

BOGUSEAW LESNODORSKI

\title{
DOMINIUM MARIS BALTICI
}

Wśród wielu zainteresowań naukowych Adama Vetulaniego do najważniejszych należą studia nad „Lennem pruskim” i nad instytucjami w Prusach niegdyś Książęcych ${ }^{1}$. Eączyły się te studia przed laty z szerszymi zainteresowaniami w krakowskim środowisku naukowym. Był ich rzecznikiem także Władysław Konopczyński. Stanisław Kutrzeba wysunął w r. 1934 temat Stosunek Prus Królewskich do Korony w latach 1454-1569 na konkurs, urządzany wówczas jak corocznie przez koło prawników, Bibliotekę Słuchaczów Wydziału Prawa Uniwersytetu Jagiellońskiego. Wziąłem udział w tym konkursie, w którym przede mną wystąpiło wielu przyszłych pracowników naukowych. Uzyskałem pierwszą nagrodę. Stanisław Kutrzeba, jak również Adam Vetulani, przyjęli taki też temat mojej rozprawy doktorskiej, na której podstawie uzyskałem stopień doktora prawa w r. $1938^{2}$. Nie obyło się bez przeszkód. Wychodząc poza materiały drukowane, sięgnąłem m. inn. do recesów toruńskich, nie zostałem pomimo interwencji Polskiej Akademii Umiejętności i Komisariatu RP w Gdańsku dopuszczony do Archiwum Gdańskiego przez władze hitlerowskie ${ }^{3}$.

Sięgam dzisiaj pamięcią do tamtych czasów, by pochylić się z największym szacunkiem przed tradycjami naukowymi i wychowawczymi

1 A. Vetulani, Lenno pruskie od traktatu krakowskiego do śmieci księcia Albrechta 1525-1568, Kraków 1930 (praca nagrodzona przez PAU); tenże, Polskie wpływy polityczne w Prusiech Ksiażęcych, Gdynia 1939; tenże, Prawny stosunek Prus Książęcych do Polski (1466-1637), Czas. Prawno-Hist., 1954, VI, 1.

2 Stosunek prawno-państwowy Prus Królewskich do Korony w latach 14541569, maszynopis w Archiwum UJ, ss. 578. Druk rozpoczęto w Instytucie Bałtyckim w Gdyni, w 1939 r., materiały uległy zniszczeniu przez Niemców.

${ }_{3} \mathrm{Cz}$. Biernat, Spór archiwalny polsko-gdańsko-niemiecki w okresie międzywojennym, 1919-1939, Warszawa 1969, s. 152, 161, 177, 178. Na s. 152 fotokopia pisma Archiwum Państwowego w Gdańsku do Senatu W. M. Gdańska z 1936 r. w mojej sprawie z informacją, że dopuszczenie do materiałów gdańskich będzie służyć „wyraźnie wrogiej propagandzie” polskiej. Decyzje zapadły zresztą w Berlinie. 
Uniwersytetu Jagiellońskiego i by wziąć udział w uczczeniu zasług dia nauki i kultury narodowej Profesora Adama Vetulaniego.

Dominium Maris Baltici to nazwa polskiego programu bałtyckiego, który wybiegał poza li tylko układy koniunktur wewnętrznych i międzynarodowych, sprecyzowanego przez komisarza króla i Rzeczypospolitej w Gảańsku u schyłku panowania Zygmunta Augusta, biskupa Stanisława Karnkowskiego. Dominium maris - oto czego żądał Karnkowski dla swego monarchy i państwa. Hasło dźwięczne i dumne, pisze Władysław Konopczyński, treść skromna 4. Oto Polacy w przeciwieństwie do innych państw bałtyckich, także Hanzy, pod swoim dominium rozumieć mieli jedynie gospodarkę na własnym brzegu i na wodach przybrzeżnych, tudzież zwierzchnictwo nad brzegami książęcego lenna w Prusach oraz Kurlandii i Inflant po Rygę. Byle mieć swoje porty i garść statków i okrętów, o żadnym innym dominium z ujmą dla cudzej swobody Rzeczpospolita nie myślała. Tylko chwilami poprzez minimalny i li tylko obronny program morski przebłyskiwała śmielsza myśl ekspansji, gdy to trzy ćwierci ludności i omal całe mieszczaństwo były zainteresowane $\mathrm{w}$ wykonaniu programu wyzyskania, ewentualnie zdobycia, gdy przed wyzyskaniem stały jakieś jeszcze przeszkody, wolnych portów od Szczecina po Rygę włącznie.

Jedno było pewne, że jakiekolwiek formy i rozmiary przybierał program morski dawnej Rzeczypospolitej, podstawę dla niego, dla wszelkich działan stanowić musiały przede wszystkim Prusy Królewskie i ich porty, zwłaszcza Gdańsk. Oczywiście w razie rozumnego i celowego ich wyzyskania w tym celu. Od urzeczywistnienia tych myśli zawisł rozkwit lub zastój ziem pruskich.

Zagadnienie to, wbrew pozorom, nie było dotąd w pełni rozpatrzone naukowo. Zajmowano się z osobna położeniem prawnym Gdańska i stosunkami polsko-gdańskimi, zagadnieniem floty wojennej ${ }^{5} \mathrm{i} \mathrm{w}$ tym zakresie uzyskaliśmy ostatnio obszerną monografię poświęconą słynnej galeonie Zygmunta Augusta 6. Pisano o „strażnikach morza” 7. Zajęto

1 Wł. Konopczyński, Polska polityka battycka, Roczniki Historyczne, III, 143 n.

K. Lepszy, Dzieje floty polskiej, Gdańsk - Bydgoszcz - Szczecin 1947. Do całości sprawy: St. Gierszewski, Myśl morska w Polsce XVI-XVIII w., Komunikaty Instytutu Bałtyckiego, VII, z. 12, s. $3 \mathrm{nn}$. (ogólny przegląd zagadnienia). Por. W1. Czapliński, Pokój szczeciński $1570 \mathrm{r}$. na tle sytuacji politycznej w basenie Mo$r z a$ Baltyckiego, Zapiski Historyczne, XXXVII, 1972, z. 2; J. Pirożyński. Na drodze do gdańskiej deprekacji. Sprawa gdańska na sejmie 1570 r., Rocznik Gdański, XXXI, 1971. zesz. 1.

6 MI. Boczar, Galeona Zygmunta Augusta. Próba rekonstrukcji, Warszawa 1973.

- S. Bodniak, Pierwsi ,strażnicy morza", w: Księga pamiatkowa ku czci W. Sobieskiego, Kraków 1932; tenże, Żotnierze morscy Zygmunta Starego (1517-1522), Rocznik Gdański, IX i X, Gdańsk 1936. 
sie również zagadnieniem pierwszego urzędu w tych sprawach, Komisją Morską, co ma znaczenie także dla instytucji dawnego państwa i prawa polskiego ${ }^{8}$.

Czy można jednak mówić o programie morskim w znaczeniu rozwiniętej i odpowiednio ustrukturalizowanej doktryny? Obejmującej nie tylko pewne zagadnienia, lecz całość pożytków płynących z morza? Okazuje się, że tak, aczkolwiek rzeczywiście ujęcia te były chwilowe, pozbawione konsekwencji. Gdy zaś rozległ się znany okrzyk Stanisława Staszica ,Trzymajmy się morza”, było już za późno nie tylko ze względu na ochronę dostępu do morza i pożytki z niego płynące, ale i Prusy Królewskie, prowincję Rzeczypospolitej jedną z najważniejszych.

Odróżnić przytem trzeba ekspansję, program więc ewentualnie zaborczy, którego trudno byłoby pochwalać, od rozwiniẹtych założeń wyzyskania dostępu do morza i gospodarki morskiej. I oto podejmując trop moich pierwszych naukowych studiów, powstałych w środowisku krakowskim, pragnę przypomnieć jedną cząstkę, niemało ważną, dociekań i wystąpień Karnkowskiego, jak i późniejszą powiązaną z nimi publicystykę.

Pojęcie dominium i imperium maris przechodziło w dawnej Polsce rozmaite koleje. Czasem obejmowano nim zaledwie tylko zabezpieczenie portów dla swobodnego handlu, czasem pełniejsze opanowanie morza przez flotę handlową i wojenną, innym razem wyzyskanie portów jako źródel dochodu dla króla i państwa. Negował natomiast jeżeli nie zawsze doktrynalnie, to praktycznie owo dominium Gdańsk, który Królestwu Fzeczypospolitej tyle tylko przyznawał praw do morza, ,dokąd koń doplynął, a kula armatnia dosięgnąc mogła". Nie w imię uprzedzeń do Polski, jak to przyjmowała dawniejsza literatura niemiecka, lecz własnych, egoistycznych korzyści.

W drugiej połowie XVI wieku pojawiła się koncepcja zwierzchnictwa Polski na morzu i praw królewskich w programie wspomnianej Komisji Morskiej. Stąd przeszła do edyktów gdańskich Karnkowskiego, niesłusznie nazwanych ,konstytucjami”. W artykule pierwszym zatytułowanym De regalibus et iure regio znajdujemy wyraźnie sformułowane pojęcia ius maritimum i maris imperium. Nie należy jednak ich identyfikować z naruszeniem słynnej zasady wolności mórz. Szło tu o udział w pożytkach płynących z morza, o to, aby ,nie odwracać się" od morza.

Stanowiąc interpretację wcześniejszych przywilejów Gdańska, powierzają edykty Karnkowskiego ,zarząd żeglugi” miastu, a królowi pozostawiają „moc nakazu i zakazu” oraz sądownictwo w sprawach żeglugi

* S. Bodniak, Komisja morska Zygmunta Augusta, Rocznik Gdański IV, Gdańsk 1931. W wykonaniu imperium czy dominium maris Komisja spełniała rolę dwu nam wspólczesnych organów administracji państwowej: urzẹdu morskiego i admiralicji. Por. K. Lepszy, dz. cyt., 104. 
z tym, że „użycie żeglugi i władza nad wybrzeżem” mają być wykonywane tylko $\mathrm{z}$ wiedzą i wolą monarchy lub jego zastępcy. Bo pełne władztwo nad morzem, „właściwe morza imperium i dominium bezpośrednio jako najważniejszy zastaw wojny i pokoju" pozostawać ma właśnie w swobodnej dyspozycji królów ${ }^{9}$. Ono jest podstawą wszelkich praw królewskich. $Z$ tego też punktu widzenia interpretując przepisy przywileju z r. 1457, orzekła Komisja, której przewodniczył Stanisław Karnkowski, że podpada karze, kto chciałby naruszać prawa króla do władztwa nad morzem. Takie ujęcie rzeczy zaprzeczało Gdańskowi prawa dowolnego zamykania i otwierania portu.

Wzmacniała zasadę przepisana w artykule VII-mym edyktów przysięga komendanta portu na wierność królowi i Królestwu i poszanowania dobra Korony Królestwa Polskiego, ziem pruskich i miasta Gdańska zarazem ${ }^{10}$.

Znalazł więc swój prawny wyraz polski program morski, skrystalizowany wokół przewodniego hasła imperium maris, więc zagadnień prawa publicznego, a zawierający istotne elementy celowej polityki morskiej, po części rozwijane w praktyce i zdolne służyć za podstawę dalszej rozbudowy ${ }^{11}$. Zespolono bowiem, jak wiadomo, silniej w r. 1569 ziemie pruskie $\mathrm{z}$ Koroną, dokonano w aktach Komisji Karnkowskiego rewizji stosunku Gdańska do Korony (zgodnie z prawem obowiązującym formalnie już od inkorporacji), stworzono zawiązek floty, w postaci Komisji Morskiej ustanowiono organ specjalny do spraw morskich.

Ale nie koniec na tym. Biskup kujawski, dobry prawnik i zręczny dyplomata, jest autorem przygotowanego przezeń dla użytku Henryka Walezego zbioru praw pruskich pt. De iure provinciali terrarum maiorumque civitatum Prussiae; wydanego drukiem w Krakowie w r. 1574. W przedmowie dziełka, które nawiązuje do ówczesnych pojęć prawa narodów i zaczątków międzynarodowego prawa handlowego, udzielił on nowemu królowi wielu rad, jak rządzić w Polsce, osobliwie zaś na Pomorzu toruńsko-gdańskim. Rady zostały ujęte w przejrzystą tabelę. Wyjaśnia tabela, zamieszczona przy końcu dziełka, pojęcie imperium maris i podaje, na czym polegają różne dziedziny tego władztwa w sensie prawno-publicznym, zwłaszcza gospodarczym, to jest dominium directum i utile $\mathrm{w}$ rozumieniu autora. Wyraziście kreśli on obraz rzeczy, jakie to ze

9 Volumina legum, II, $809 \mathrm{nn}$.

Morze stanowiło także dla prawa polskiego ,rzecz pospolitą, publiczną”, której użytek winien być wolny dla żeglugi i innych pożytków z mocy praw boskich, przyrodzonych i ludzkich. Por. P. Dąbkowski, Zarys prawa polskiego prywatnego, Lwów 1921, 66.

10 Volumina legum, j.w.

11 St. Bodniak, Morze $w$ głosach opinii $w$ dawnej Polsce, Rocznik Gdański, IV i V, 1930/31, 80 n. Por. A. Szelągowski, Walka o Bałtyk, Lwów 1904, rozdz. V i VI. 
wszech miar pożyteczne płyną konsekwencje, jakie mogą być i są wyniki wytężonej działalności na morzu i wybrzeżu. Nie jest to rozróżnienie precyzyjne, o pośrednich prawach Karnkowski w ogóle nie wspomina. Ma własną koncepcję suwerenności i gospodarowania. Daje natomiast, jak zauważono zresztą nazbyt mocno i nazbyt szeroko „na wskroś nowożytny pogląd na znaczenie morza". W każdym razie rzuca się w oczy szerokie potraktowanie imperium - dominium maris.

Pozwalam sobie ogłosić na tym miejscu interesującą tabelę Karnkowskiego jako niespodziewanie poważny wyraz dawnej myśli morskiej w Polsce. Jeżeli Roman Rybarski w zasadzie słusznie zaznaczył, że ,głównym niedomaganiem zagranicznej polityki handlowej Polski był brak podstawowego jej pierwiastka - polityki morskiej" ${ }^{12}$, tym wyraźniej wybija się znaczenie takiego wystąpienia, jak memoriał Karnkowskiego. Morze stawało się w tym rozumieniu czynnikiem, który wpływa na bieg i kierunek ewolucji społecznej i gospodarczej. W zakresie ustrojowym oddziaływuje na doniosły proces zrastania się kraju w jednolity organizm. Systemat dorzecza Wisły, królewskich czyli publicznych rzek spławnych stawał się jednością komunikacyjną wraz z morzem, wraz z czerpaniem z niego różnych pożytków. Jedność ta stawała się z kolei podstawą dla centralizacji społeczno-ekonomicznej i politycznej ${ }^{13}$.

Co więcej, książka Karnkowskiego nie była czymś jedynym i samotnym w polskiej (i pomorsko-gdańskiej) myśli. Sprawa wolności mórz i wybrzeży, portów, i racjonalnej gospodarki, m. in. walki z piractwem na Bałtyku, powróciła $\mathrm{w}$ dyskusjach $\mathrm{z}$ lat trzydziestych i czterdziestych XVII wieku, które pozostawiły po sobie ślad w paru drukach ogłoszonych po łacinie, w języku polskim i niemieckim ${ }^{14}$. Tym razem wypowiadali się mieszkańcy miast pomorskich. W głębi Rzeczypospolitej zainte-resowania marynistyczne na dłuższy czas zanikły. Były to już inne czasy.

„Bezpośrednie” władztwo morza obejmuje w tym ujęciu uprawę żeglugi, możność budowy portów i składów, także poza Gdańskiem (a chodziło tu najwyraźniej o to, co i później, mianowicie przy niewątpliwej trwałości związków. z Gdańskiem i Gdańska z Polską o możliwość tego, by również „gdzieś wyżej portu udziałać”, jak proponował już Mikołaj

12 R. Rybarski, Handel i polityka handlowa Polski $w$ XVI stuleciu, I-II, Poznań 1928-1929.

${ }_{13}$ O zasadzie wolności mórz i zarazem czerpania z nich pożytków: Th. W. Fulton, The Sovereignthy of the Sea, 1911; M. de Taube, Le statut juridique de la Mer Baltique jusqu'au debut du XIX-e siecle, Ac. de Droit Intern., Recueil des cours, LIII, 1935/III; R. Bierzanek, Wolność mórz w świetle korespondencji dyplomatycznej Zygmunta Augusta, Państwo i Prawo, 1952, z. 1.

14 J. Pfenning, Praeconsul Civitatis Mariaeburgensis, Antimare Balticum... jak również: Mare Balticum id est historia... (druk anon.) i inne. Na broszurę tę zwrócił moją uwagę doc. W. Góralczyk z UW w ślad za pracą St. Huberta, Stan $i$ potrzeby badań polskiej nauki prawa międzynarodowego do końca XVIII w. Wrockaw 1951. 
dispositioncm navigationis, qua est, facultas sive potestas pace belloque, pro modo temporum, locorum, sentium, personarum et mercium classes expediendi et navigationes quaslibet permittendi, prohibendi, inusitatesque et

directo

quod

continet

\section{Imperium}

maris

consisitt

in

dominio:

$$
\text { cipiendi }
$$

portus novos

propugnacula in portibus. ostiis et litoribus maris

cmporia maritima

iacultarem vectigalia sive portoria constituendi maritima

expeditiones maritimac

militares

$\begin{array}{ll}\text { iudicia } & \text { piratarum } \\ \text { maiora } & \text { nautarum quorumlibet } \\ \text { ct minora } & \end{array}$

negociatorum et quorum.

viscunque mare navigantium

utili

ut sunt

piscatura

omnia generis

electrum vel succinum,

sal et id genus alia

morces

naufragae copiosa mercatura et negociatio rerum transmarinarum et sic rerum necessa-

quorum

omnium

est finis

um abundantia

divitiae ex mercibus domesticis

exoticarum rerum praecii utilitas

defensio regnorum et provinciarum

hostis depressio

splendor domesticus

amplitudo et potentia

regni et provinciarum

reditus ingentes thesauri publici et privati et multa alia

iustitia

$\mathrm{pax}$

fir: is defensio littorum,

portuum et provinciarum. 
Rey), uprawnienie do wznoszenia warowni nadmorskich, ustanawianie opłat portowych, sądownictwo w tych sprawach, w razie zaś potrzeby i prowadzenie wojny na morzu. Zwierzchnictwo według ówczesnej terminologii „użytkowe" miało zapewnić rybołóstwo, wydobywanie bursztynu i innych skarbów morza. Rozporządzanie żeglugą prowadziło do zasobnego kupiectwa i rozkwitu handlu, do ,rzeczy przydatnych obfitości", a zatem dobrobytu, do korzystnej ceny towarów zamorskich, jak i do skutecznej obrony kraju.

Możnośc budowy i rozbudowy portów przynosi, głosił Karnkowski, ,splendor domowy", zwiększa siłę państwa. Prawnika uderza w omawianej tabeli użycie nie tylko terminu dominium, ale właśnie imperium. $\mathrm{Z}$ władztwem chodziło tu $\mathrm{w}$ parze administrowanie $\mathrm{w}$ najszerszym tego słowa znaczeniu, w wysokiej mierze o charakterze gospodarczym.

Polski przykład zastosowania koncepcji dominium maris $w$ znaczeniu iuris utendi, alienandi, libere disponendi - dotarly $m$. inn. przez znaną na Zachodzie prace J. Januszowskiego na karty pism J. Seldena (1635) i C. Van Bynkershoeka (1702, II wyd. 1744) ${ }^{15}$. Diuzsza ewolucja zasad i norm prawa morskiego objęła od przelomu XVI i XVII wieku jego istote $\mathrm{i}$ formę. W pierwszym zakresie ścieraly się ze sobą dążenia do zapewnienia wolności mórz przez redukcję uprawnień państw ze sobą rywalizujacych i szczególnych uprawnien mocarstw, i przeciwne temu interesy partykularne $w$ nadzorze i reglamentacji żeglugi oraz w eksploataci bogactw morza, jego wnętrza i dna, zwłaszcza wód przybrzeżnych. W zagadnieniach morskich współuczestniczyły ze sobą i ścierały się normy zwyczajowe, zmieniane lub uściślane przez układy bilateralne oraz tendencje do stanowienia powszechnego prawa morskiego w coraz szerszej mierze i zawierania konwencji wielostronnych obok układów bilateralnych, szczególowych ${ }^{16}$.

15. J. Januszowski, Statuta, prawa i konstytucje koronne, lacińskie $i$ polskie... W Krakowie 1600, s. 109; C. Van Bynkershoek, De dominio maris dissertatio, wstęp J. B. Scotta, New York 1923.

${ }_{16}$ J. Higgins - G. Colomb, The International Law of the Sea, London 1945; G. Rippert, Droit maritime, I, Paris 19504; Coll, Dalloz, Répertoire de droit international, II, Paris 1969. 


\section{DOMINIUM MARIS BALTICI}

R és u m é

Dominium Maris Baltici c'est le nom d'un programme marin polonais, fait en 2 ème moitié du XVIe siècle par l'évêque de Kujawy, Stanisław Karnkowski. Les Polonais ne prétendaient pas à conquérir la domination sur la mer faisant la guerre. Ils ne voulaient que posséder quelques ports et une petite flotte. Ils comprenaient Dominium Maris comme l'administration de la côte de Baltique, la mise à profit les eaux territoriales et la suprématie sur les bords de Baltique jusqu'à la ville de Riga. La base du dominium devait être la Prusse-Orientale avec ses ports, y compris sûrtout la ville de Gdańsk. Cependant Gdańsk reduisit, au nom de ses propres avantages égoistes, les droits du royaume polonais d'administrer les eaux territoriales.

S. Karnkowski prépara aussi un édit pour la ville de Gdańsk où il fit la révision des relations de Gdańsk avec le royaume polonais. Bien que le roi polonais ait confié l'administration de la navigation à la ville de Gdańsk, le pouvoir législatif et juridique appartenaient au roi lui-même ou à son délégué. Dès lors les autorités de Gdańsk n'avaient plus le droit de libre ouverture et fermeture du port et le commandant du port devait prêter serment de la fidélité au roi et au royaume polonais. On a organisé également l'appareil spécial pour les questions marines - une Commission Marine - et un germe de la flotte.

S. Karnkowski publia en 1574 à Cracovie la collection des lois prussiens destinée pour le roi Henri de Valois. Karnkowski y donna plusieurs conseils sur la maniére de gouverner la Pologne et il les a composés en tableau, expliquant de cette façon l'idée de l'imperium maris et de ses différents domaines. L'auteur du tableau posede sa propre conception de la souveraineté et de l'administration nationale et on y remarque également la jonction des notions de l'imperium et du dominium maris.

Le tableau publié ci-dessus est très intéressant. Il exprime l'ancienne idée marine en Pologne. Au XVIIe siècle existaient encore dans la société les intérêts pour la mer, mais l'époque suivante les a mis au second rang. 